\title{
Echinotermes biriba, a new genus and species of soldierless termite from the Colombian and Peruvian Amazon (Termitidae, Apicotermitinae)
}

\author{
Daniel Castro', Rudolf H. Scheffrahn², Tiago F. Carrijo ${ }^{3}$ \\ I Instituto Amazónico de Investigaciones Cientificas SINCHI, Avenida Vásquez Cobo Calles 15 y 16, Leticia, \\ Amazonas, Colombia 2 Fort Lauderdale Research and Education Center, Institute for Food and Agricultural \\ Sciences, University of Florida, 3205 College Avenue, Davie, Florida 33314, USA 3 Centro de Ciências Natu- \\ rais e Humanas, Universidade Federal do ABC, Rua Arcturus 03, Jardim Antares, 09606-070, São Bernardo \\ do Campo, SP, Brazil \\ Corresponding author: Daniel Castro (danielkaz80@gmail.com)
}

Academic editor: D. Evangelista | Received 5 February 2018 | Accepted 14 March 2018 | Published 4 April 2018

http://zoobank.org/27364E47-1566-48B0-8757-OB5E32A4COAA

Citation: Castro D, Scheffrahn RH, Carrijo TF (2018) Echinotermes biriba, a new genus and species of soldierless termite from the Colombian and Peruvian Amazon (Termitidae, Apicotermitinae). ZooKeys 748: 21-30. https://doi. org/10.3897/zookeys.748.24253

\begin{abstract}
A new Apicotermitinae genus and species Echinotermes biriba is described from workers collected on the Andean-Amazon Piedmont in Colombia and Peru. The enteric valve armature of Echinotermes biriba Castro \& Scheffrahn, gen. et sp. n. is a remarkably diagnostic character. A Bayesian phylogenetic analysis using the COI gene and including all other Neotropical Apicotermitinae genera, supports the new genus as a distinct terminal.
\end{abstract}

\section{Keywords}

Anoplotermes-group, enteric valve, Neotropic, taxonomy

\section{Introduction}

The soldierless termites of Amazonia form a dominant group and comprise more than $30 \%$ of the termite diversity in neotropical assemblages (Davies 2002, Ackerman et al. 2009, Palin et al. 2011). Although the richness of soldierless taxa is recognized,

Copyright Daniel Castro et al. This is an open access article distributed under the terms of the Creative Commons Attribution License (CC BY 4.0), which permits unrestricted use, distribution, and reproduction in any medium, provided the original author and source are credited. 
most have not been described yet (Bourguignon et al. 2015). For example, Palin et al. (2011) list four undescribed Anoplotermes species and 18 undescribed species in 13 undescribed genera from Peru. Originally, all neotropical soldierless termites were placed in the genus Anoplotermes Müller, 1873. Recognition of much greater taxonomic diversity began with Mathews (1977) who described Grigiotermes and Ruptitermes, and Fontes (1986) who described Aparatermes and Tetimatermes. Fontes (1992) provided the first identification key for workers of these five genera. The descriptions of Longustitermes (Bourguignon et al. 2010), Compositermes (Scheffrahn 2013), Amplucrutermes, Humutermes, Hydrecotermes, Patawatermes, and Rubeotermes (Bourguignon et al. 2016), and Disjunctitermes (Scheffrahn et al. 2017) have advanced the classification of neotropical soldierless taxa but many more remain to be described.

Currently, 13 genera and 52 species of Apicotermitinae are known from the Neotropical region (Bourguignon et al. 2010; Krishna et al. 2013; Scheffrahn 2013; Carrijo et al. 2015; Bourguignon et al. 2016; Scheffrahn et al. 2017). For Colombia, Anoplotermes ater, Anoplotermes parvus, Aparatermes silvestrii, Humutermes krishnai, and Patawatermes turricola have been reported (Araujo 1977; Constantino 1998; Bourguignon et al. 2016; Pinzón et al. 2017), and Peru records include Anoplotermes banksi, Anoplotermes pacificus, Disjunctitermes insularis, Rubeotermes jheringi, and Ruptitermes reconditus (Constantino 1998, Bourguignon et al. 2010, Acioli and Constantino 2015, Bourguignon et al. 2016, Scheffrahn et al. 2017). Only 19\% of the species of Apicotermitinae of the Neotropics are reported in these two countries.

In this paper Echinotermes biriba gen. n. et sp. n. is described based on the morphology of the worker caste and molecular data.

\section{Materials and methods}

The specimens were collected and preserved in $75 \%$ or $85 \%$ ethanol. The dissection of the enteric valve (EV) was done by removing the P2 tube from the worker's gut and then expelling all the food particles by means of controlled pressure. The tube was immersed in a PVA medium to completely detach the EV from surrounding muscle tissue and cut longitudinally to splay open the EV for mounting in the medium. The mandibles were also submerged in PVA medium. The terminology used for the worker gut follows Sands (1972) and Noirot (2001).

The COI sequence of E. biriba was obtained by DNA extraction and PCR performed by the Canadian Centre for DNA Barcoding following standard high-throughput protocols (deWaard et al. 2008). The PCR employed the primers LepF1 and LepR1 (Hebert et al. 2003) which generated 622 to 652bp of the barcode region of the mitochondrial gene cytochrome c oxidase subunit 1 (COI).

A gene tree was created under Bayesian Inference (BI) using the COI gene. In addition to the sequence of $E$. biriba, a total of 48 GenBank sequences were used: 34 sequences of neotropical Apicotermitinae (21 species, 13 genera), eight non neotropical Apicotermitinae genera, five non-apicotermitine Termitidae, and one Rhinotermiti- 
dae, (Heterotermes crinitus) as the outgroup. Sequences were aligned under MUSCLE algorithm implemented in Geneious v6.1.6 (Biomatters Ltd., Auckland, New Zealand). Substitution model used $(G T R+I+G)$ was selected through the Akaike Information Criterion (AIC) with the software jModelTest2 (Darriba et al. 2012). The XML input files were generated with BEAUti 1.8.0, and the BI was performed with BEAST 1.8.0 (Drummond et al. 2012). A Yule speciation process, with a random starting tree, and relaxed molecular clock was used as tree priors. Four Markov chain Monte Carlo (MCMC) searches were conducted, each one for 15,000,000 generations, and they were combined to search the most probable tree. Convergence and stationarity were assessed with Tracer 1.5 (Rambaut et al. 2014) and the first 600 trees were discarded as burn-in with TreeAnnotator 1.8.0 and visualized using FigTree 1.3.1.

\section{Systematics}

Echinotermes Castro \& Scheffrahn, gen. $n$. http://zoobank.org/9872DC61-CA8C-42B5-9ABE-62160F532ECD

\section{Type-species. Echinotermes biriba sp. n. \\ Imago. Unknown.}

Description of worker. (Fig. 1). Monomorphic. Head capsule and antennae a light yellowish colour; pronotum pale yellow; legs hyaline. Head covered with approx. 30 longer setae $(0.1 \mathrm{~mm})$ and approx. 100 shorter setae $(\leq 0.05 \mathrm{~mm})$ (Fig. 1A). In lateral view, dorsal surface of the head capsule slightly convex; postclypeus is moderately inflated. Antennae with 14 articles. Pronotum with four or five long setae and numerous short hairs. Mandibles with apical teeth more prominent than first marginal teeth; left mandible with $\mathrm{M} 1+2$ equilateral, M3 forming right angle, molar prominence projecting in line with apical tooth; right mandible with concave margin between M1 and M2 (Fig. 1B).

Fore-tibia moderately inflated (Fig. 1C) and covered with approx. 60 longer setae and approx. 40 shorter setae; pilosity denser apically. Third (external) spur very small. Femur with approx. 20 sparse large setae. Tibial spurs 2:2:2.

Digestive tube (Fig. 1D) with very large crop, more voluminous than paunch (P3). Mesenteron forming complete $360^{\circ}$ loop. Mesenteric tongue short, truncate. First proctodeal segment tubular, equal diameter throughout and visible its entire length in ventral view. Enteric valve seating trilobed, with smaller lobe not visible in intact gut. Enteric valve with six cushions, terminating at the opening to the $\mathrm{P} 3$ as spiny spheroids (Fig. 2).

Diagnosis. The crop of E. biriba is unusually large and the enteric valve armature, consisting of six spherical pectinate pads, is unique among all apicotermitine genera.

Remarks. Mandibles of Rubeotermes jheringi and Humutermes krishnai are very similar to E. biriba, but the first marginal teeth of E. biriba are less prominent that those two genera. The diagnostic character of E. biriba is the enteric valve armature which is also spiked in the Humutermes enteric valve (EV) but in E. biriba the EV 

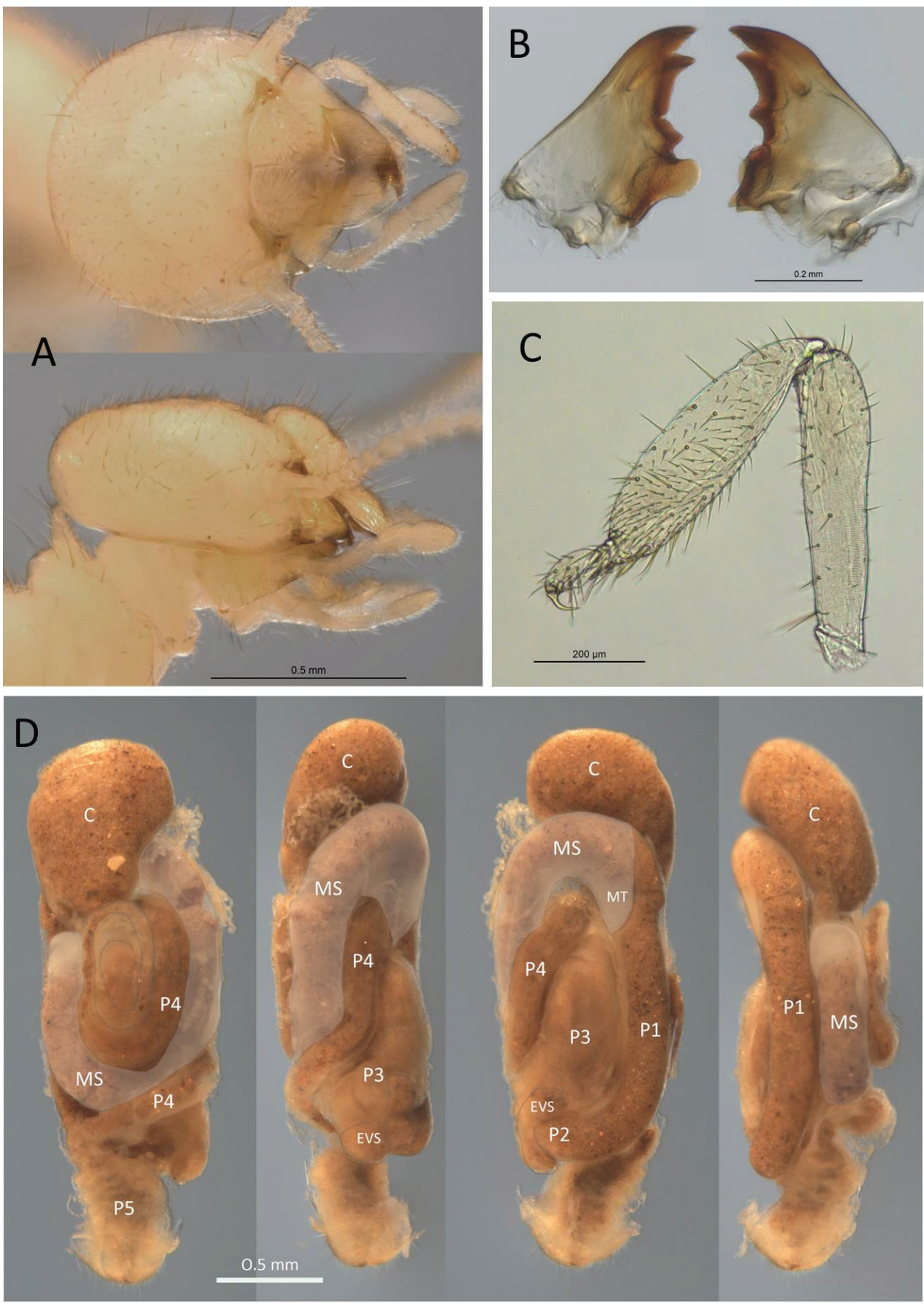

Figure I. Worker of Echinotermes biriba sp. n.: A dorsal and lateral views of head and pronotum $\mathbf{B}$ mandibles $\mathbf{C}$ right fore-tibia $\mathbf{D}$ digestive tube from left to right: dorsal, right, ventral and left views. Abbreviations: $\mathrm{C}=$ crop, $\mathrm{EVS}=$ enteric valve seating, $\mathrm{MS}=$ mesenteron, $\mathrm{MT}=$ mesenteric tongue $\mathrm{P} 1-\mathrm{P} 5$ = proctodeal segments. 


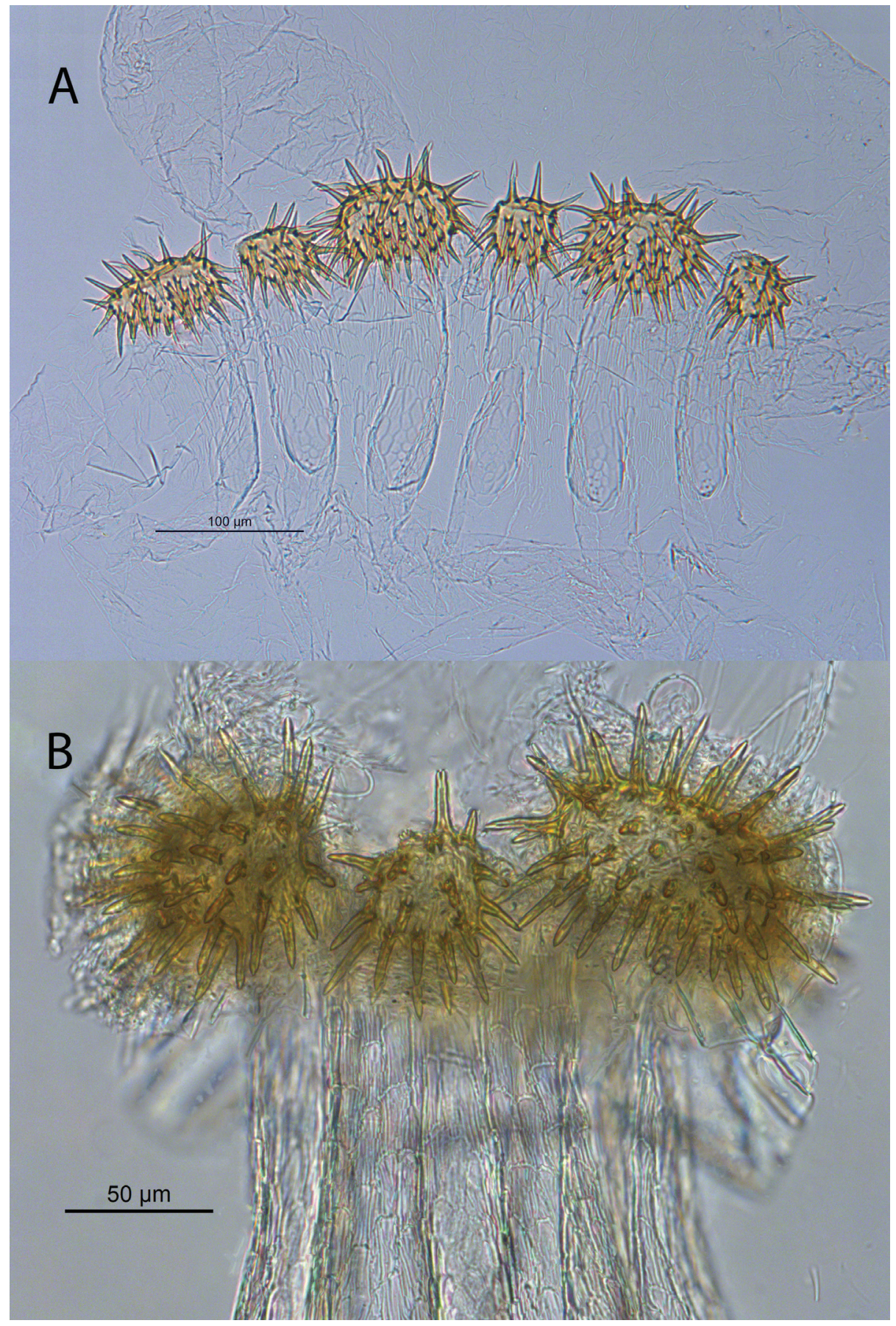

Figure 2. Worker enteric valve of Echinotermes biriba sp. n. A Spliced mount B whole mount, showing in situ position of armature. Note the filamentous bacteria attached to the spines. The trilobed seating anterior to the spines (removed in this preparation) is full of bacteria and devoid of food particles, referred by Noirot (2001) as the "bacterial pouch". 
armature is spherical while in Humutermes it is rather flat. Humutermes species are smaller than Echinotermes. The enteric valve of Grigiotermes is composed of six uniform pectinate plates, while in Patawatermes the uniform plates are hemispherical.

Etymology. From the Latin Echino, meaning spiny, describing the EV armature.

Echinotermes biriba Castro \& Scheffrahn, sp. n.

http://zoobank.org/9F9BC8F4-57E9-4608-BB48-FBE9E481940B

Holotype. Worker from colony CATAC 2736.

Type-locality. COLOMBIA: Caquetá, Belén de los Andaquíes (1.60794, -75.88683).

Paratypes. PERU: Pasco, Oxapampa, Chatarra forest, (-10.51303, -75.07276), 24/05/2014, 556 m, 14 workers (UF no. PU 144). Additional material: COLOMBIA: Caquetá, Belén de los Andaquíes, Camino Andaquí (1.60794, -75.88683), 31/01/2017, $625 \mathrm{~m}, 10$ workers (CATAC 2736).

Description of worker. (Fig. 1, Table 1) EV armature consists of six prominent spheroids each covered with robust spiny armature; three larger (ca. 30-35 spines) and three smaller (15-20 spines) alternate inside the EV seating. Enteric valve with six unsclerotized cushions some four times longer than wide, each composed of approx. 10-20 ovoid scales.

Diagnosis. Unique armature of EV composed of alternating larger and smaller spheroids covered with robust spines.

Remarks. See genus remarks above.

Ecology and distribution. In Colombia, E. biriba foragers were collected in the same soil sample (0-10 cm depth) with Longustitermes manni. Gut contents confirm that E. biriba feeds on soil organic matter. This species is only known from the Chatarra forest in the southern Peruvian Amazon, and in a mature secondary forest in the northern Colombian Amazon (Fig. 4).

Molecular analysis. The gene tree recovered the Neotropical Apicotermitinae (NA) as monophyletic, however, the position of Echinotermes biriba inside this clade could not be established with this single gene. The low posterior probability of almost

Table I. Measurements ( $\mathrm{mm}$ ) of ten workers from two colonies of Echinotermes biriba sp. n.

\begin{tabular}{l|c|c|c|c|c}
\hline \multirow{2}{*}{ Holotype } & \multirow{2}{*}{ Nen } & \multicolumn{2}{|c|}{ PU144 } & \multicolumn{2}{c}{ CATAC2736 } \\
\cline { 3 - 6 } & & Range & Mean & Range & Mean \\
\hline Max Head Width & 0.74 & $0.77-0.74$ & 0.75 & $0.83-0.74$ & 0.78 \\
\hline Pronotum Width & 0.44 & $0.49-0.46$ & 0.48 & $0.44-0.55$ & 0.51 \\
\hline Hind Tibia Length & 0.57 & $0.53-0.44$ & 0.48 & $0.61-0.55$ & 0.57 \\
\hline Fore Tibia Length & 0.48 & $0.44-0.35$ & 0.41 & $0.49-0.43$ & 0.46 \\
\hline Fore Tibia Width & 0.13 & $0.14-0.11$ & 0.12 & $0.14-0.11$ & 0.12 \\
\hline Fore Tibia Width: Length Ratio & 0.27 & $0.36-0.24$ & 0.30 & $0.23-0.28$ & 0.26 \\
\hline
\end{tabular}




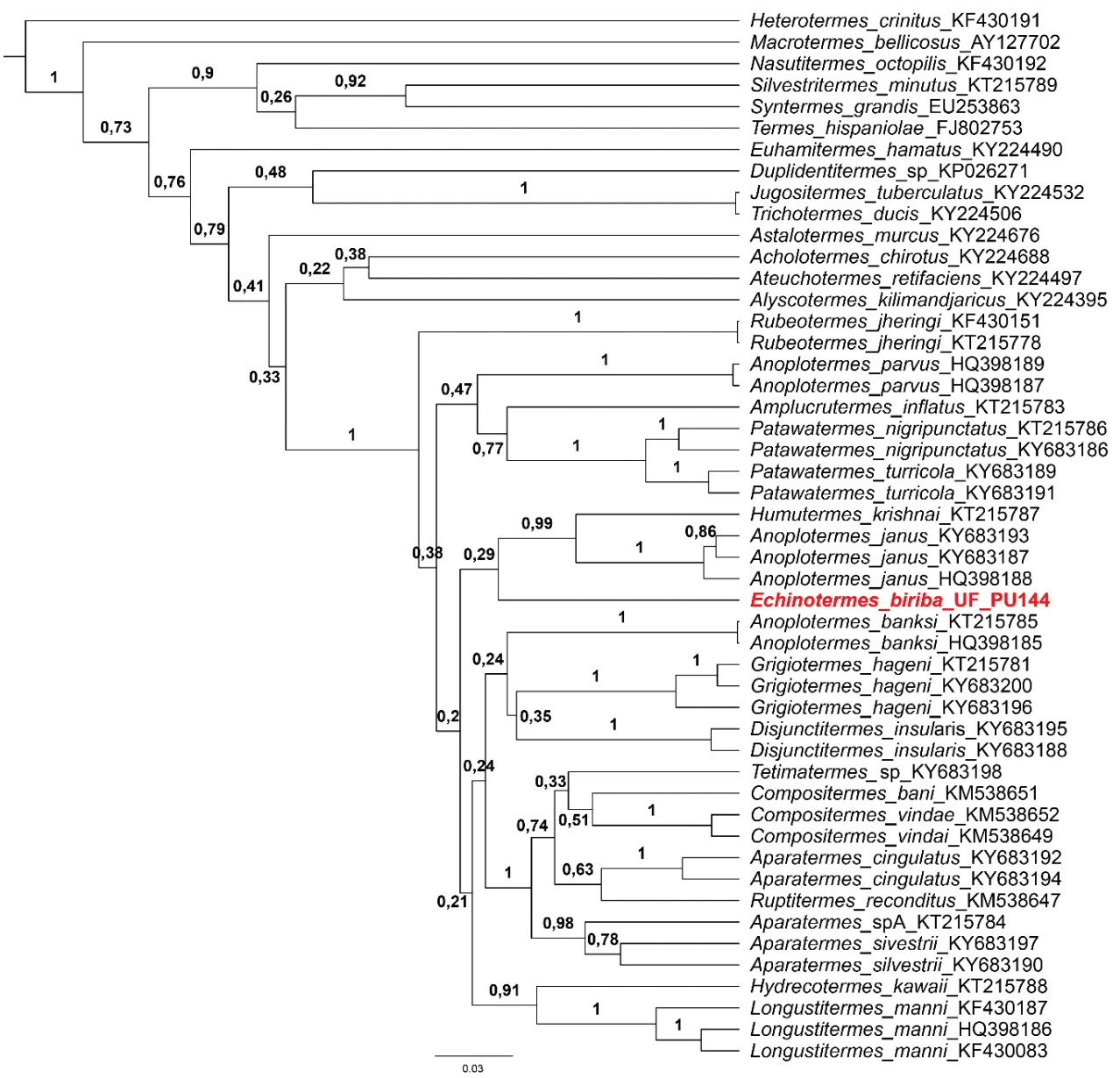

Figure 3. Bayesian gene tree of all described soldierless New World genera using the mitochondrial COI barcode gene showing posterior probabilities. Tree rooted on terminal Heterotermes crinitus.

every first branching clades in the NA group should be interpreted as a big polytomy, and the new genus as a branch in this polytomy, just as most of the other NA genera (Fig. 3).

Etymology. The species name is due to the resemblance of the EV armature with the Amazonian fruit Rollinia mucosa (Jacq.) Baill. which is known as "biriba" in the region.

\section{Discussion}

Neotropical soldierless termites have been a taxonomic problem to a large extent because enteric valve (EV) morphology was overlooked. Mathews (1977) showed it was possible to differentiate some New World Apicotermitidae using the EV as had already 


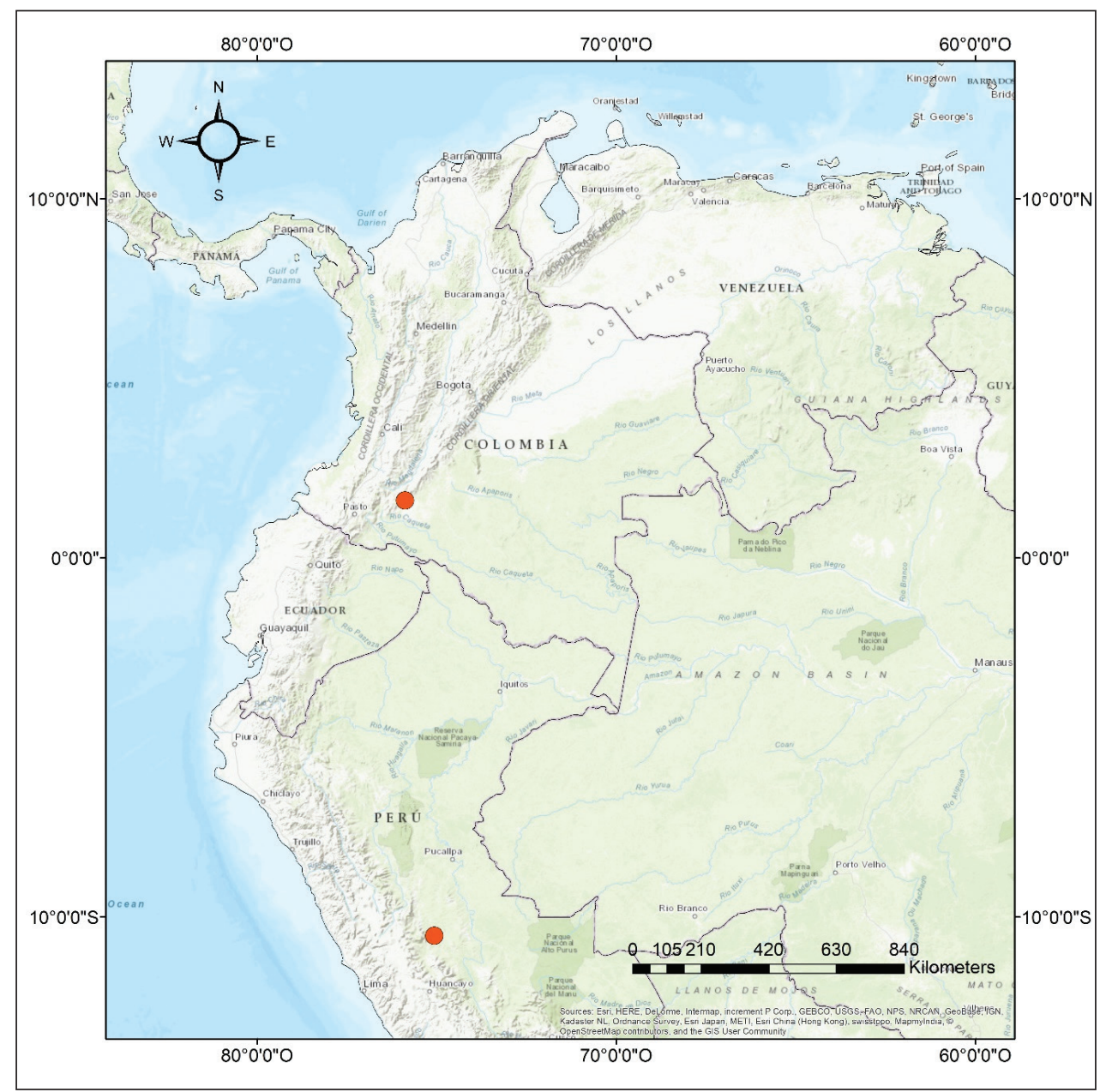

Figure 4. Known localities of Echinotermes biriba sp. n.

been done in Africa (Grassé and Noirot 1954, Sands 1972), thus furthering the reclassification of the so-called Anoplotermes-group to this day. As with D. insularis (Scheffrahn et al. 2017), E. biriba is described only from the worker caste with the EV as its most robust diagnostic character.

The Amazon forest contains the greatest diversity of New World termites (Ackerman et al. 2009, Constantino and Cancello 1992), but currently the data show a low diversity of Apicotermitinae compared to other subfamilies such as Nasutitermitinae, Syntermitinae, and Termitinae (Constantino 1991, de Souza and Brown 1994). As new genera and species of neotropical Apicotermitinae are described, the richness of termites, especially in poorly studied countries such as Colombia and Peru will greatly increase. 


\section{Acknowledgments}

We want to thank to the Colciencias, Instituto Amazónico de Investigaciones Científicas SINCHI and Expedición BIO project for the financial support in Colombian Amazon. We also thank to Dr. Clara P. Peña-Venegas for coordinating the soil component at SINCHI and for her logistic support on field trips. We heartily thank the reviewers for their help in improving the paper.

\section{References}

Acioli AN, Constantino R (2015) A taxonomic revision of the neotropical termite genus Ruptitermes (Isoptera, Termitidae, Apicotermitinae). Zootaxa 4032(5): 451-492. http://dx.doi. org/10.11646/zootaxa.4032.5.1

Ackerman IL, Constantino R, Hugh G, Gauch J, Lehmann J, Riha SJ, Fernandes ECM (2009) Termite (Insecta: Isoptera) species composition in a primary rain forest and agroforests in Central Amazonia. Biotropica 41: 226-233. http://dx.doi.org/10.1111/j.1744-7429.2008.00479.x

Araujo RL (1977) Catálogo dos Isoptera do Novo Mundo. Rio de Janeiro: Academia Brasileira de Ciências, 92 pp.

Bourguignon T, Scheffrahn RH, Křeček J, Nagy ZT, Sonet G, Roisin Y (2010) Towards a revision of the Neotropical soldierless termites (Isoptera: Termitidae): redescription of the genus Anoplotermes and description of Longustitermes, gen. nov. Invertebrate Systematics 24: 357-370. http://dx.doi.org/10.1071/IS10012

Bourguignon T, Šobotník J, Dahlsjö CAL, Roisin Y (2015) The soldierless Apicotermitinae: insights into a poorly known and ecologically dominant tropical taxon. Insectes Sociaux 63: 39-50. https://doi.org/10.1007/s00040-015-0446-y

Bourguignon T, Scheffrahn RH, Nagy ZT, Sonet G, Host B, Roisin Y (2016) Towards a revision of the Neotropical soldierless termites (Isoptera: Termitidae): redescription of the genus Grigiotermes Mathews and description of five new genera. Zoological Journal of the Linnean Society 176: 15-35. https://doi.org/10.1111/zoj.12305

Carrijo TF, Scheffrahn RH, Křeček J (2015) Compositermes bani sp.n. (Isoptera, Termitidae, Apicotermitinae), a new species of soldierless termite from Bolivia. Zootaxa 3941: 294298. http://dx.doi.org/10.11646/zootaxa.3941.2.10

Constantino R (1991) Termites (Isoptera) from the lower Japurá River, Amazonas State, Brazil. Boletim do Museu Paraense Emílio Goeldi 7: 189-224.

Constantino R, Cancello EM (1992) Cupins (Insecta, Isoptera) da Amazônia Brasileira: distribuição geográfica e esforço de coleta. Revista Brasileira de Biologia 52(3): 401-413.

Constantino R (1998) Catalog of the living termites of the New World (Insecta: Isoptera). Arquivos de Zoologia 35(2): 135-231. https://doi.org/10.11606/issn.2176-7793.v35i2p135-230

Darriba D, Taboada GL, Doallo R, Posada D (2012) jModelTest 2: more models, new heuristics and parallel computing. Nature Methods 9: 772-772. http://dx.doi.org/10.1038/nmeth.2109

Davies RG (2002) Feeding group responses of a Neotropical termite assemblage to rain forest fragmentation. Oecologia 133: 233-242. https://doi.org/10.1007/s00442-002-1011-8 
de Souza O, Brown V (1994) Effects of habitat fragmentation on Amazonian termite communities. Journal of Tropical Ecology 10: 197-206. https://doi.org/10.1017/S0266467400007847 deWaard JR, Ivanova NV, Hajibabaei M, Hebert PD (2008) Assembling DNA Barcodes: analytical Protocols. In: Martin C (Ed.) Methods in Molecular Biology: Environmental Genetics, Humana Press Inc., Totowa USA, 275-293. https://doi.org/10.1007/978-1-59745-548-0_15

Drummond AJ, Suchard MA, Xie D, Rambaut A (2012) Bayesian Phylogenetics with BEAUti and the BEAST 1.7. Molecular Biology and Evolution 29: 1969-1973. http://dx.doi. org $/ 10.1093 / \mathrm{molbev} / \mathrm{mss} 075$

Fontes LR (1986) Two new genera of soldierless Apicotermitinae from the Neotropical region (Isoptera, Termitidae). Sociobiology 12(2): 285-297.

Fontes LR (1992) Key to the genera of New World Apicotermitinae (Isoptera: Termitidae). In: Quintero DA, Aiello A (Eds) Insects of Panama and Mesoamerica. Oxford University Press, New York, 242-248.

Hebert PD, Cywinska A, Ball S, deWaard J (2003) Biological identifcations through DNA barcodes. Proceedings of the Royal Society of London series B - Biological Sciences 270: 313-321. https://doi.org/10.1098/rspb.2002.2218

Grassé PP, Noirot C (1954) Apicotermes arquieri (Isoptere): ses constructions, sa biologie. Considerations generales sur la sousfamille des Apicotermitinae nov. Annales des Sciences Naturelles, Zoologie (11)16(3/4): 345-388.

Krishna K, Grimaldi DA, Krishna V, Engel MS (2013) Treatise on the Isoptera of the world. 4. Termitidae (part one). Bulletin of the American Museum of Natural History 377: 973-1494. https://doi.org/10.1206/377.4

Mathews AGA (1977) Studies on Termites from the Mato Grosso State, Brazil. Academia Brasileira de Ciências, Rio de Janeiro, 267 pp.

Noirot C (2001) The gut of termites (Isoptera). Comparative anatomy, systematics, phylogeny. II. Higher termites (Termitidae). Annales de la Société Entomologique de France 37: 431-471.

Palin OF, Eggleton P, Malhi Y, Girardin CA, Rozas-Dávila A, Parr C (2011) Termite diversity along an Amazon-Andes elevation gradient, Peru. Biotropica 43(1): 100-107. Https:// doi.org/10.1111/j.1744-7429.2010.00650.x

Pinzón OP, Baquero LS, Beltran MA (2017) Termite (Isoptera) diversity in a gallery forest relict in the Colombian eastern plains. Sociobiology 64(1): 92-100. https://doi.org/10.13102/ sociobiology.v64i1.1184

Rambaut A, Suchard MA, Xie D, Drummond AJ (2014) Tracer v1.6. http://tree.bio.ed.ac.uk/ software/tracer/ [23/01/2018]

Sands WA (1972) The soldierless termites of Africa (Isoptera: Termitidae). Bulletin of the British Museum (Natural History) Entomology 18: 1-244

Scheffrahn RH (2013) Compositermes vindai (Isoptera: Termitidae: Apicotermitinae), a new genus and species of soldierless termite from the Neotropics. Zootaxa 3652: 381-391. http:// dx.doi.org/10.11646/zootaxa.3652.3.6

Scheffrahn RH, Carrijo TF, Postle AC, Tonini F (2017) Disjunctitermes insularis, a new soldierless termite genus and species (Isoptera, Termitidae,Apicotermitinae) from Guadeloupe and Peru. ZooKeys 665: 71-84. https://doi.org/10.3897/zookeys.665.11599 